\title{
An unusual occurrence of the Laurentian phyllocarid crustacean Ceratiocaris papilio Salter in the lower Ludfordian (Silurian) of Bohemia (peri-Gondwana)
}

\author{
PETR BUDIL, JOSEPH COLLETTE \& ŠTĚPÁN MANDA
}

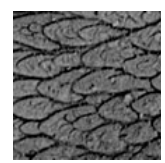

\begin{abstract}
A rich assemblage $(n=223)$ of well-preserved phyllocarid crustacean remains is described from offshore calcareous shales of the Kopanina Formation (Silurian, Ludlow, early Ludfordian, Saetograptus linearis Biozone) exposed near the village of Všeradice, SE of Beroun. Specimens examined fall within the intraspecific variability of Ceratiocaris papilio Salter in Murchison, 1859, which is widely distributed in the Llandovery and Wenlock of Laurentia. Consequently, the Bohemian specimens represent the first occurrence of C. papilio outside of Laurentia. Additionally, the phyllocarid assemblage from Bohemia is younger than that of Laurentia. In Bohemia, Ceratiocaris papilio occurs in finely laminated calcareous shales. Its abundance varies distinctly from bed to bed, and phyllocarids are the dominant faunal component in only a few beds. Phyllocarids are associated with common graptolites and pelagic orthocerids while other benthic organisms are severely limited. Isolated or articulated furcae and telsons, and isolated mandibles are the most common components of this association, but articulated abdominal segments with caudal appendages (but without carapaces) also occur. An exceptional, slightly disarticulated specimen has articulated abdominal and partial thoracic segments, with mandibles preserved in situ. Additional possible occurrences of C. papilio and related species in Bohemia are also discussed. • Key words: Phyllocarida, crustaceans, palaeocology, biostratigraphy, Silurian, Prague Basin, Czech Republic.
\end{abstract}

Budil, P., Collette, J. \& MANDA, Š. 2010. An unusual occurrence of the Laurentian phyllocarid crustacean Ceratiocaris papilio Salter in the lower Ludfordian (Silurian) of Bohemia (peri-Gondwana). Bulletin of Geosciences 85(4), 551-564 (10 figures). Czech Geological Survey, Prague. ISSN 1214-1119. Manuscript received September 13, 2010; accepted in revised form October 7, 2010; published online November 1, 2010; issued December 20, 2010.

Petr Budil \& Štěpán Manda, Czech Geological Survey, Klárov 3, 11821 Praha 1, Czech Republic; petr.budil@geology.cz, stepan.manda@geology.cz $\bullet$ Joseph Collette, Department of Earth Sciences, University of California, Riverside, CA; joseph.collette@email.ucr.edu

Phyllocarid crustaceans are common in offshore facies in Přídolí and Lochkovian strata of Bohemia (Chlupáč 1994). In contrast, phyllocarids from Llandovery, Wenlock and Ludlow sedimentary succession are rare and remain poorly known. A few specimens were described by Barrande (1872) and by Novák in his unpublished manuscript (Novák 1887) and briefly commented on by Chlupáč (1994). Many authors (e.g., Bouček 1937, Horný 1955 and Kříž 1992) have reported phyllocarid remains from various localities and biozones. However, these specimens are typically too poorly preserved to allow identification to the species level, and most have thus been assigned to Ceratiocaris $\mathrm{sp}$. These occurrences nevertheless suggest that phyllocarids may be a common component of assemblages present in shale facies since the early Ludlow in the Prague Basin.

In 2009, Petr Štorch and Štěpán Manda conducted a detailed examination of the shale-dominated late Gorstian-early Přídolí sequence of the Kopanina Formation exposed in a temporary trench located NW from the village of
V̌seradice (Fig. 1). A sequence more than $60 \mathrm{~m}$ thick was sampled for graptolites. Surprisingly, numerous well-preserved phyllocarid remains were found in shales of early Ludfordian age. Mandibles, articulated furcae, and partially articulated abdomens are most common, but more complete remains of other exoskeletal parts were also found.

\section{Occurrence of Ceratiocaris papilio}

The Všeradice section is situated on the SW flank of the Prague Synform, NE from the village of Všeradice (Fig. 1). In palaeogeographic and tectonic models of the Prague Basin, the Všeradice section is situated in the so-called western segment of the basin, which is characterized by deeper water hemi-pelagic sedimentation and intensive subsidence (Křǐž 1991, 1992, 1998). The Všeradice section was briefly described by Horný (1960), and investigated in detail by Kříž (1992), Kř́iž et al. (1993), Kozlowska et al. 

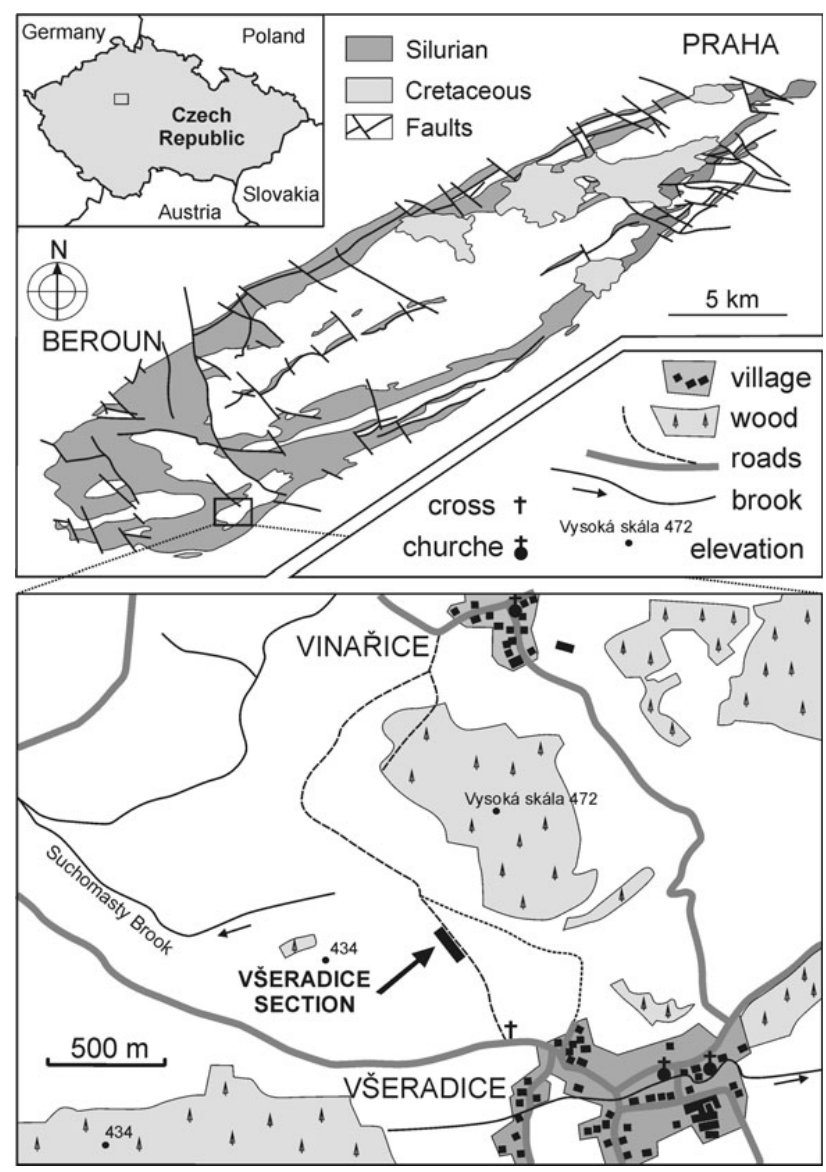

Figure 1. Distribution of the Silurian rocks in the Prague Basin and the location of the V̌reradice V̌̌-2 pit.

(2001) and Manda \& Kř́̌ž (2006). The base of the shale-dominated Všeradice section is middle Wenlock and continues up to the early Př́idolí. Limestones (mostly argillitic mudstones) and tuffites form thin beds in shales locally. Shales contain abundant graptolites and ostracods (Entomis and Bolbozoe), while straight cephalopods (e.g. Parakionoceras originale) and bivalves (e.g. Cardiola) are less common. Rare dendroid graptolites, inarticulate brachiopods, trilobites, crinoids, monoplacophorans and microconchids occur in a few isolated beds only. The Všradice sections thus represent a deeper water offshore setting, while a lack of benthos suggests prevailing anoxic bottom conditions.

Phyllocarids occur only in part of the section (beds 42-62; note that low section numbers represent younger beds, while higher numbers represent older beds). Phyllocarid remains are most abundant in beds 56-62, and are rather rare in other beds in which they also occur (Fig. 2). Based on graptolite biostratigraphy, phyllocarids appear $50 \mathrm{~cm}$ above the base of Saetograptus linearis Zone and disappear at the base of Bohemograptus tenuis Zone (Petr Štorch, personal communication), and are absent from both the underlying and overlying beds. Because of

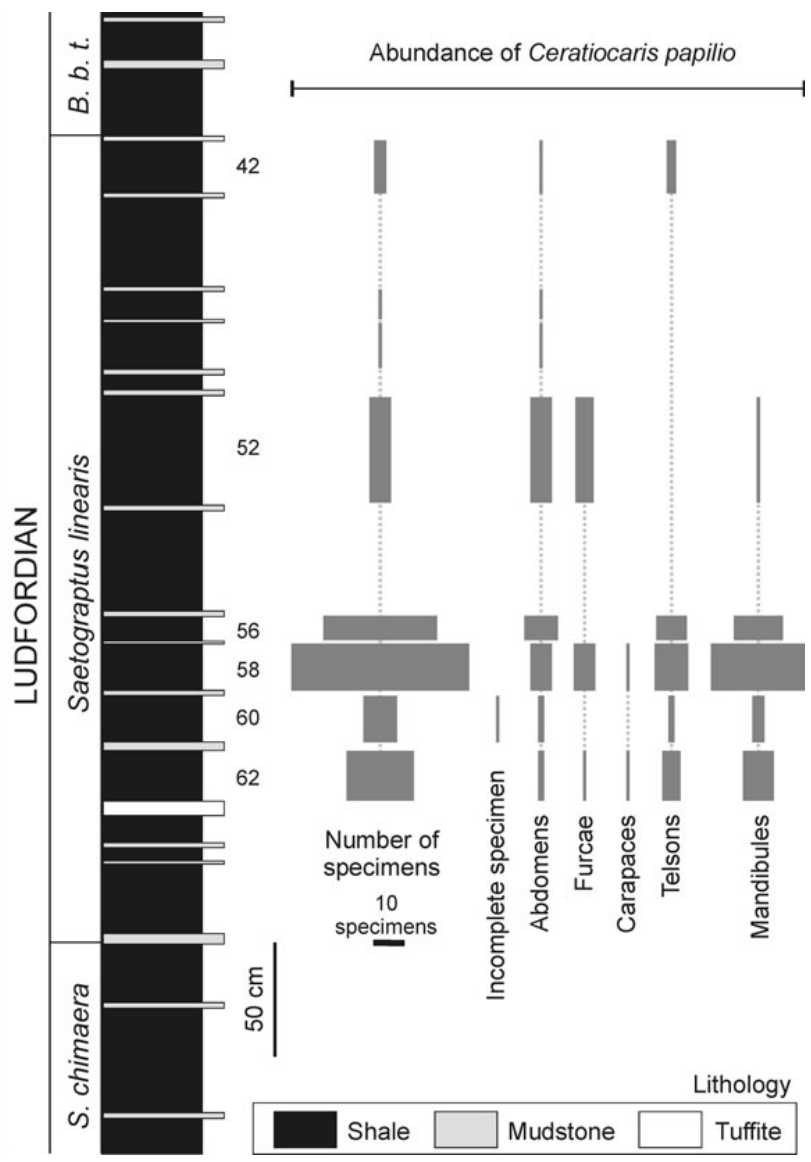

Figure 2. Abundance of Ceratiocaris papilio at the Všeradice VŠ-2 pit section. For exact number of phyllocarid remains, see Appendix.

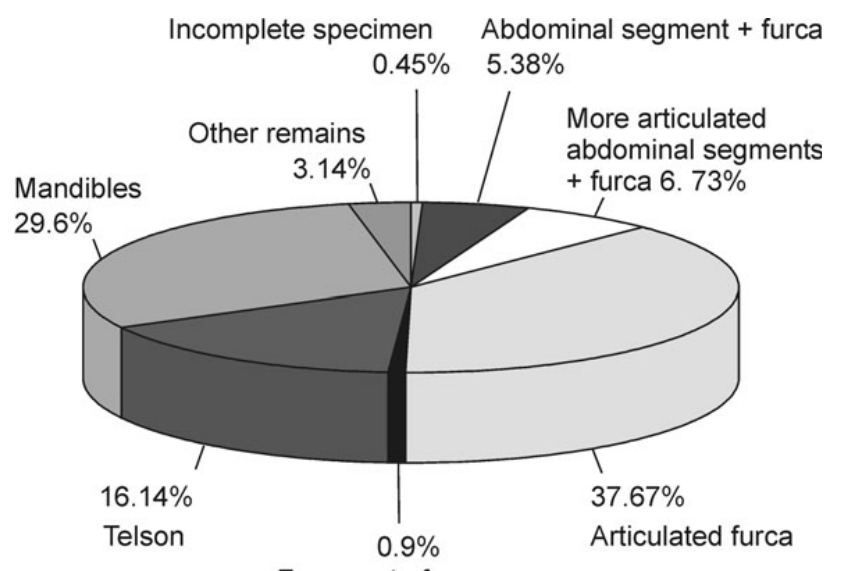

Fragment of carapace

Figure 3. Ratio of phyllocarid remains in entire association in the V̌̌eradice VŠ-2 pit section.

the uniform lithology of the shales, and the similar taphonomic conditions throughout phyllocarid-bearing beds, it is unlikely that phyllocarid occurrences restricted exclusively to the shales of the Saetograptus linearis Zone represent a preservational bias. In coeval shallow water 

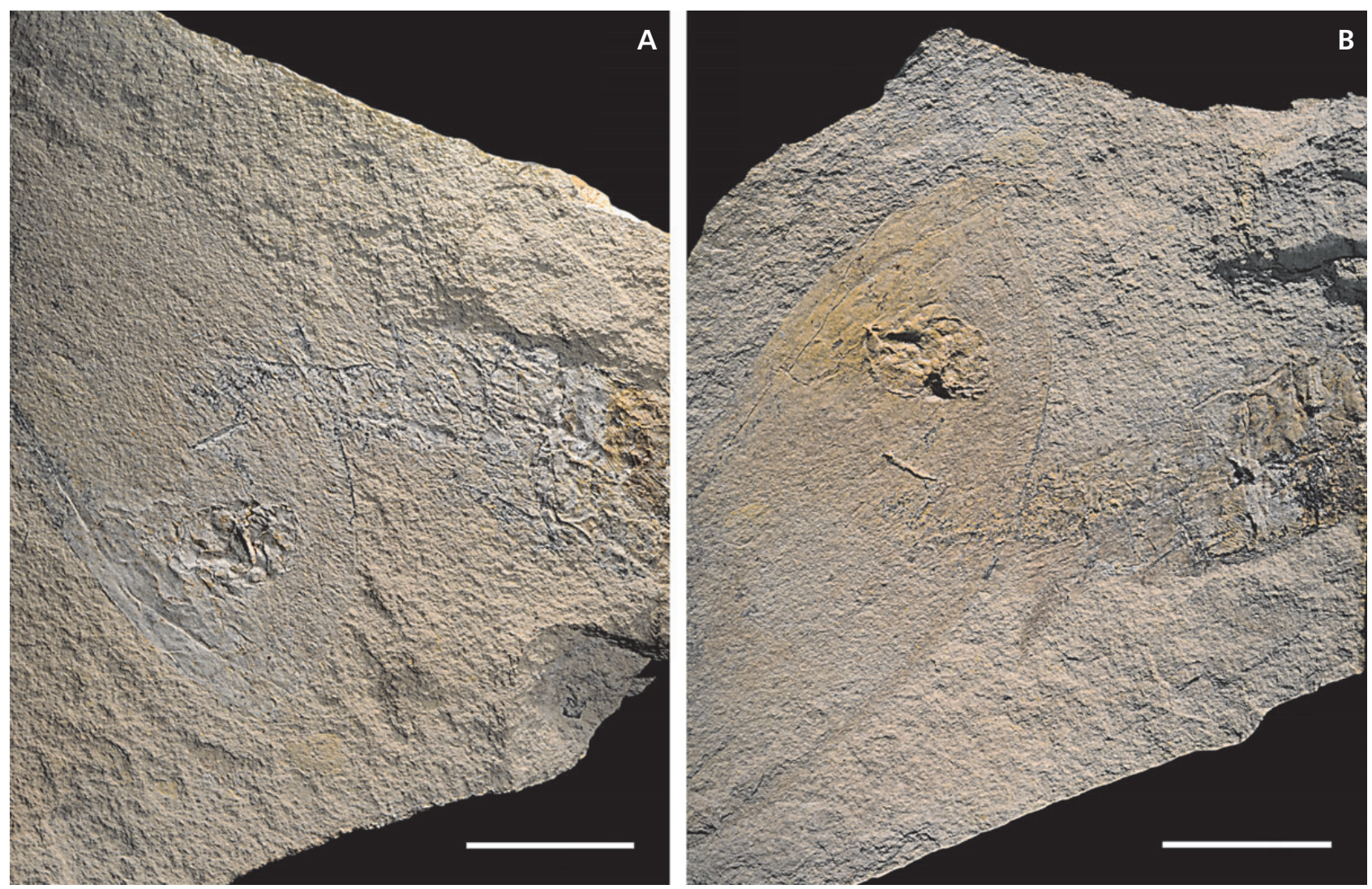

Figure 4. Ceratiocaris papilio Salter in Murchison, 1859. Lower Ludfordian, Silurian, Kopanina Formation, Všeradice, VŠ-2 pit. • A, B - left valve of the carapace with displaced but articulated thoracic and abdominal somites. A - positive part, CGS PB 505b; B - the same specimen, a negative counterpart. Scale bars $=1 \mathrm{~cm}$.

setting, the Saetograptus linearis Zone corresponds with prominent shallowing (limestones banks with Metacalymene baylei, e.g., Kosov and Mušlovka quarries) and basinward extension of carbonate facies (see Horný 1955, Kříž 1992, Manda \& Kř́ž 2006). This extension is consistent with assumed global low-stand in the S. leintwardinensis Zone (replacing the Bohemian Saetograptus linearis Zone on the global scale) suggested by Johnson et al. (1998) and others. Additionally, small-scale slumps in shales and a tuffite (bed No. 43) contain benthic remains of shallow water provenance in the Saetograptus linearis Zone of the Všeradice section; such remains are also consistent with shallowing in this part of the basin. Consequently, the phyllocarid population in Všeradice is restricted to low stand. Ceratiocaris papilio disappears in bed No. 42; this level corresponds with a graptolite extinction known as the Leintwardinensis Event (for summary see Melchin et al. 1998, Manda \& Kříž 2006).

Phyllocarid remains from the Všeradice section are flattened but otherwise well-preserved; only mandibles are preserved in relief. Sculpture is commonly clearly visible. Presence of specimens with significant articulation or their parts (e.g. furcae) are indicative of a low energy environment with no significant transport. Even disarticulated exoskeletal elements are well-preserved (e.g. long, narrow telson spines are often preserved intact). An interesting exception to this lack of transport appears to be local accumulations of mandibles on some bedding planes. Abundance and type of phyllocarid remains are given in Figs 2 and 3.

Depository. - All specimens from the Všeradice section are stored in the collection of Petr Budil (prefix PB) in the Czech Geological Survey, Praha, Czech Republic. Comparative material and Barrande's types are deposited in National Museum, Praha (prefix L).

\section{Systematic palaeontology}

Class Malacostraca Latreille, 1806

Subclass Phyllocarida Packard, 1879

Order Achaeostraca Claus, 1888

Family Ceratiocarididae Salter, 1863

\section{Genus Ceratiocaris M'Coy, 1849}

Type species. - Ceratiocaris solenoides M'Coy, 1849. Silurian, Ludlow, Westmoreland. 
Diagnosis. - See Collette \& Rudkin (2010), p. 119.

Bohemian species assigned. - C. sp. ex gr. papilio Salter in Murchison, 1859, Silurian, Llandovery-Wenlock, Motol Formation; C. cf. scharyi Barrande, 1872, Silurian, Wenlock, Motol Formation; C. inaquealis Barrande, 1872, Wenlock, Motol Formation; C. docens Barrande 1872, Ludlow, Kopanina Formation; C. scharyi Barrande, 1872, Silurian, Ludlow, Kopanina Formation; C. papilio Salter in Murchison, 1859, Silurian, Ludlow, Kopanina Formation; C. bohemica Barrande, 1872, Silurian, Přídolí, Požáry Formation.

\section{Ceratiocaris papilio Salter in Murchison 1859}

Figures 4A, B, 5A-F

1859 Ceratiocaris papilio n. sp.; Salter in Murchison, p. 262, text-figure 1 .

1860 Ceratiocaris papilio Salter in Murchison. - Salter, pp. 155, 156, text-figure 1.

1860 Ceratiocaris stygius (Salter in Murchison). - Salter, p. 156 , text-figs 2,3 .

1865 Ceratiocaris papilio Salter in Murchison. - Woodward, pp. 401-403, pl. 11, figs 1, 2.

1885 Ceratiocaris stygia (Salter in Murchison). - Jones \& Woodward, pp. 394-397, pl. 10, fig. 2.

1888 Ceratiocaris stygia (Salter in Murchison). - Jones \& Woodward, fig. 7; pl. 11, figs 3, 7.

1896 Ceratiocaris monroei (Salter in Murchison). - Whitfield, pp. 301-302, pl. 13, figs 1-5; pl. 14, figs 3-8.

2010 Ceratiocaris monroei (Salter in Murchison). - Watkins, Meyer \& Coorough, pp. 9, 10, figs 15.4-15.5, 16.1-16.4, 17.1-17.6, 18.1-18.5, 19.1-19.8.

See Collette \& Rudkin (2010) and Collette \& Hagadorn (2010) for additional synonymy.

Material from Bohemia. - Twenty-seven well-preserved specimens including abdominal segments with furca, articulated furcae, isolated mandibles, one slightly disarticulated incomplete specimen, and three fragments of isolated carapace valves. In addition, 196 less wellpreserved, fragmentary specimens from the same locality share morphological characteristics, and are likely conspecific. All specimens included herein are from the Všeradice section.
Diagnosis. - See Collette \& Rudkin (2010), p. 119.

Description of Bohemian material. - Carapace: Incompletely known. Carapace valves subquadrate to subovate, $19.34 \mathrm{~mm}$ wide, $>45.41 \mathrm{~mm}$ long (posterior part broken, CGS PB 505a, b, see Fig. 4), estimated length to height ratio approximately 2.5 (deformed by tectonism). Cuticle very thin (see Figs 5A-D, 6B). Dorsal hinge line straight; anterodorsally produced into a slightly concave rostral notch forming the dorsal side of the carapace horn. Anterior carapace horn acuminate with blunt anterior terminus. Ventral margin broadly rounded, posterior margin unknown. A narrow thickened border is developed along the free margins of the valves; border thickest ventrally, thins slightly anteriorly and posteriorly; doublure present. Posterior margin and hinge nodes unknown. Surface of valves covered by fine longitudinal raised striae approximately parallel with carapace margins; striae regularly parallel, rarely anatomizing. Density of striae diminishes slightly from dorsal to ventral carapace margins. In specimen CGS PB 505, in situ mandibles are preserved beneath the cuticle of the carapace valves in approximately the first fifth of the carapace length. Mandibles have 7-8 teeth, and a relatively narrow base.

Thorax: Incompletely preserved. Thoracic segments of very low relief; at least six thoracic somites preserved. Segments shorter antero-posteriorly than abdominal segments, smooth (Fig. 5C, D).

Abdomen: Abdomen of seven segments, which increase in length posteriorly in unequal proportions. Segments thickened at articulating margins where articulating grooves are indicated (Fig. 7F). Anterior segments A1 and A2 short; ornamented with faint striations oriented approximately $45^{\circ}$ from the trunk axis; fine chevron-like ornament is locally present dorsally (Figs 5C, D, 6A). Posterior segments A6 and A7 most completely known; nearly entire surface of A6 and A7 covered with chevron-like ornament forming a leaf- or scale-like pattern (posterior ends of "scales" are commonly in contact). Fine striations are also present, predominantly on anterior and ventral parts of A7 and A6. This fine striation covers nearly entire surface of abdominal segments A5 anteriorly (see Fig. 5C). Finer-scale ornament described by Rolfe $(1961,1962)$ and Collette \& Rudkin (2010) has not been observed. Ratio of abdominal segment A7 to A6 is $1.74-1.98$ (mean $1.88, \mathrm{n}=8$ ).

Figure 5. A-E-Ceratiocaris papilio Salter in Murchison, 1859. Lower Ludfordian, Silurian, Kopanina Formation, Všeradice, VŠ-2 pit. • A, B - detail of the articulated mandibles, CGS PB 505. A - negative counterpart CGS PB 505b. B - the positive part of the same specimen, CGS PB 505a. $\bullet$ C - CGS PB 505b, a detail of last abdominal and the first thoracic somites, negative counterpart CGS PB 505b. $\bullet$ D - the positive part of the same specimen, CGS PB 505a. $\bullet$ E - the negative counterpart of abdominal somites A6 and A7 with articulated telson, CGS PB 506. $\bullet$ F - Ceratiocaris? sp. An unpublished holotype of Holocaris univalvis Novák MS, mentioned by Chlupáč (1994) as Ceratiocaris sp. ex gr. papilio Salter in Murchison, 1860. Llandovery, Telychian, Litohlavy Formation, section near Litohlavy water reservoir, NM L 27965. Scale bars $=5$ mm. 
Petr Budil et al. - Phyllocariid crustacean Ceratiocaris papilio in the lower Ludfordian of Bohemia
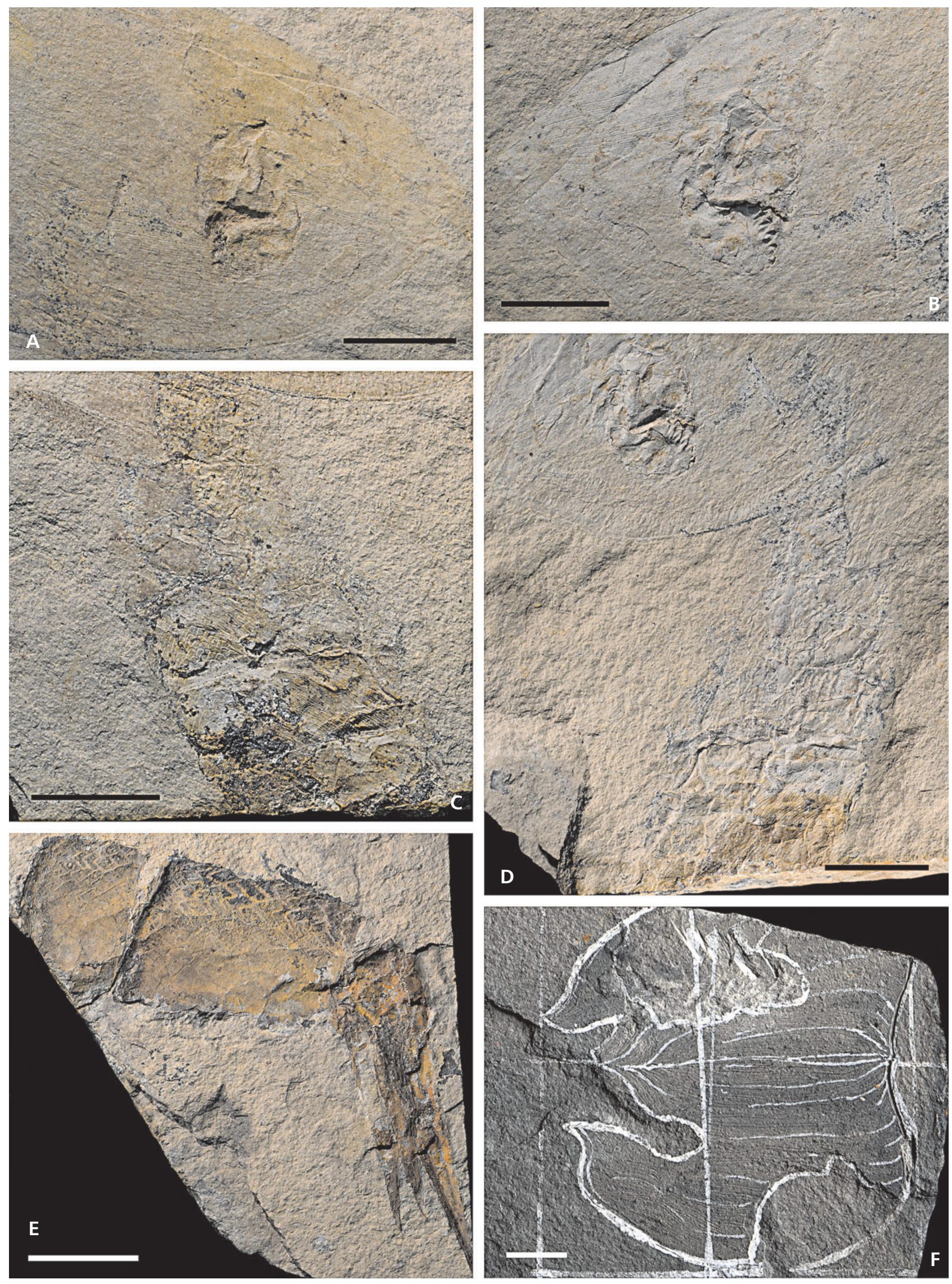
Telson and furcal rami: Telson elongate, styliform; produced into a narrow spine. Telson head robust, strongly broadened; two lateral nodes and two ventro-lateral ridges (damaged by deformation) are present in the bestpreserved material. Telson with more than four prominent postero-ventrally directed furrows. Rows of round to subround pits are present on each lateral side of telson; spacing of pits approximately uniform, but decreases posteriorly (see Fig. 5G). Furcal rami broad and flattened, styliform; taper evenly to sharp terminus. Dorsal surface smooth or with very indistinct striations, commonly with thickened margins. Distal termini of furcal rami often slightly upturned dorsally (Fig. 7A, C). Telson to furca ratio 1.55-1.97 (mean 1.79, $\mathrm{n}=10$ ).

Discussion. - Prior to the discovery of the present material, Ceratiocaris papilio Salter in Murchison, 1859 was known only from the late Llandovery to Wenlock of Laurentia, e.g. present-day Scotland, USA and Canada (Collette \& Rudkin 2010). The new material presented herein extends the range of $C$. papilio to the Ludlow (early Ludfordian, Saetograptus linearis Biozone). This is a remarkably long range for a biological species.

Morphometric ratios of Bohemian specimens agree well with ratios of Scottish material. For example, the ratio of abdominal segments A7 to A6 is 1.74-1.98 (mean = 1.88) in Czech specimens, while in Scottish specimens of C. papilio, this same ratio is $1.43-2.38$ (mean $=1.89 \pm$ 0.171 ). The telson to furca ratio of Bohemian specimens is 1.55-1.97 (mean = 1.79); this ratio for Scottish C. papilio specimens is $1.36-2.39$ (mean $=1.873 \pm 0.2278$ ). Additional morphological details that ally Czech material with other occurrences of $C$. papilio include pits for the insertion of spinules on the lateral telson surfaces, the trigonal ornament of abdominal segments, and the fine parallel rarely anastomosing striae of the carapace valves.

The observation of in situ mandibles in Czech specimens corresponds well with the estimated location of the anterior or "optic" node in specimens from other localities. This observation generally supports the interpretations of Collette \& Rudkin (2010), Rolfe (1962), and Salter in Murchison (1859) that this 'node' is probably an artifact of the very thin carapace cuticle 'draping' over the mandible. Such a consistent position of the mandible in $C$. papilio indicates the likely location of the mouth. It should be noted, however, that structures with possible sensory function occupy a similar anterolateral position in other archaeostracans taxa (see Crasquin et al. 2009 for discussion). Morphologically similar isolated mandibles occur throughout the phyllocarid-bearing parts of the studied section; these are probably conspecific with $C$. papilio.

Minor differences in morphology exist between geographic occurrences of $C$. papilio. For example, Czech specimens do not preserve the three hingeline nodes of the carapace present in some Scottish specimens, nor do they have the finer-scale trigonal micro-ornament 'overprinting' of the abdominal 'scales' preserved in specimens from the Eramosa Lagerstätte. The absence of the fine-scale ornament described by Collette \& Rudkin (2010), however, could be due to post-mortem, pre-lithification processes such as abrasion, or dissolution while the exoskeleton was exposed on the surface of the sea floor during early diagenesis (see also Chlupáč 1977), and/or by modern weathering of the silty shales. One of us (J. Collette) observed specimens of $C$. papilio from the type locality (Lenarkshire, Scotland) and also from the Eramosa Formation (Ontario) with similarly effaced areas between patches of preserved scale ornamentation that were interpreted as being caused by modern weathering. The smooth furcal rami usually present in Bohemian specimens are more atypical of Scottish and Canadian examples of C. papilio, which often display fine, parallel longitudinal striae. However, the holotype of $C$. papilio (GSM 7479, British Geological Survey, Keyworth, England) also possesses similarly smooth furcal rami (see Fig. 8).

We do not consider the minor morphological differences discussed above to be a significant departure from the range of intra-specific morphology known in $C$. papilio; thus, the new Bohemian specimens are placed within Ceratiocaris papilio. It is probable that some of these minor differences may be explained by differing local taphonomic conditions (e.g. - dissolution of fine ornamentation of the exoskeleton, flattening, tectonic deformation). The most morphologically similar ceratiocaridid "species" to the new Czech material is the invalid species Ceratiocaris stygia Salter in Murchison, 1859, considered by Rolfe \& Burnaby (1961) to be a junior synonym of C. papilio (similarities include: the carapace outline, robust and short $6^{\text {th }}$ and $7^{\text {th }}$ abdominal somites with characteristic ornamentation, robust telson and relatively broad furcal rami etc. - see Jones \& Woodward 1888, pl. 11, fig. 3). In the newly studied Bohemian association, there are no specimens larger than $8 \mathrm{~cm}$ in length for complete animals.

\section{Notes on Landovery-Ludlow phyllocarids in Bohemia and the occurrence of "Ceratiocaris papilio group"}

A stratigraphically oldest occurrence of Ceratiocaris sp. ex gr. papilio Salter in Murchison, 1859 in Bohemia (Litohlavy Formation, likely Spirograptus turriculatus Zone, Telychian) was briefly mentioned by Chlupáč (1994) in a discussion of the unpublished species "Holocaris univalvis Novák MS". This unique specimen, figured herein as Fig. 5F is too poorly preserved to be determinable. However, the supposed outline of the carapace differs from that of $C$. papilio. Without any data on abdominal and telson 

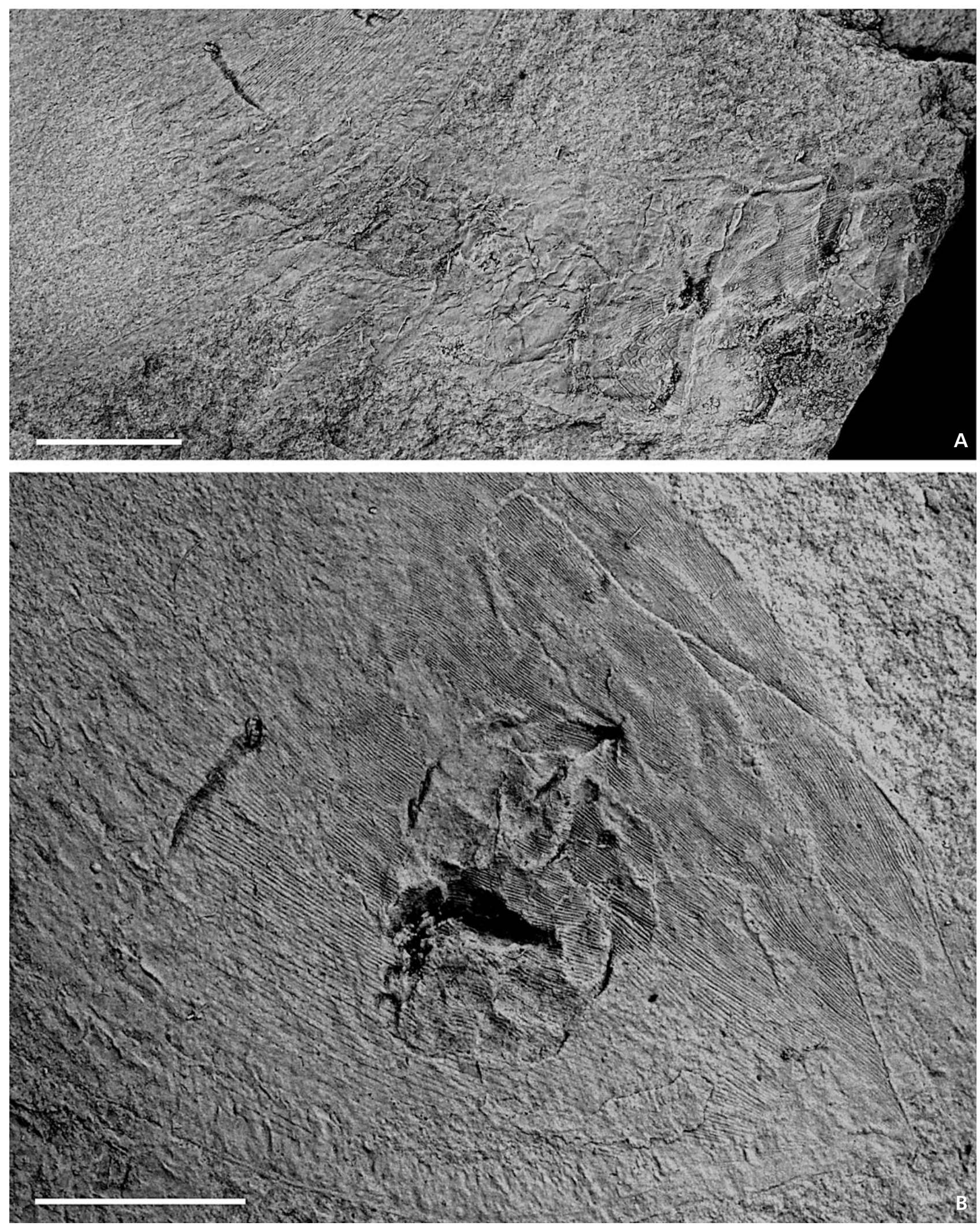

Figure 6. Ceratiocaris papilio Salter in Murchison, 1859. Lower Ludfordian, Silurian, Kopanina Formation, Všeradice, VŠ- 2 pit. Left valve of the carapace with displaced but articulated thoracic and abdominal somites, CGS PB 505a. $\bullet$ A detail of the thoracic and abdominal somites with fine ornamentation. $\bullet \mathrm{B}$ - detail of the carapace ornamentation. The specimen was coated by ammonium chloride. Scale bars $=5 \mathrm{~mm}$. 
morphology, affiliation of this specimen with the genus Ceratiocaris may be considered as questionable. Chlupáč (1994, Table 1) lists the occurrence of Ceratiocaris (C.) sp. in the Llandovery and Wenlock strata of the Bohemia; however, it is questionable whether within this indeterminable material (mostly isolated telsons without prominent longitudinal ridges) representatives of $C$. papilio could be present.

Ceratiocaris scharyi Barrande, 1872 (Ludlow, Kopanina Formation) resembles $C$. papilio in overall shape of abdominal segments, and especially in having similar sculpture (see also Jones \& Woodward 1888, p. 42). Ceratiocaris papilio and C. scharyi are closely related, but C. scharyi is distinguished from the former on the basis of its rounded leaf-like rather than chevron-like abdominal ornamentation (see Fig. 9A, B). Ceratiocaris scharyi is thus far known only from the holotype, which occurs in earlier Ludfordian limestones. Consequently $C$. scharyi is coeval with $C$. papilio in Bohemia, but it possibly inhabited a rather shallow water environment. Note that several fragments of ceratiocaridid telsons were found in the type locality and horizon of $C$. scharyi indicating that ceratiocaridids were relatively abundant there. Unfortunately, the mode of preservation and fragmentary material precludes precise determination.

Chlupáč (1994) also mentions an occurrence of $C$. cf. scharyi in the tuffaceous shale of the Monograptus belophorus Zone in the Černidla section near Loděnice (see Kř́̌z 1992 for locality description). He described a single specimen, smaller than typical C.papilio and C. scharyi, and also reported similar specimens from late Wenlock strata from Lejškov and Koněprusy localities (Chlupáč 1994), indicating that his $C$. cf. scharyi (rather $C$. aff. scharyi) is older than $C$. scharyi. Unfortunately, no specimen assigned to $C$. cf. scharyi was found in any collection in the Prague National Museum, Charles University, or the Czech Geological Survey. Consequently, a verification of Chlupáč's conclusion is impossible. The studied specimen of $C$. scharyi somewhat resembles the younger Warneticaris grata (Chlupáč, 1984) (Požáry Formation, Přídolí), but this species markedly differs from $C$. scharyi in possessing a much longer A7, ventrally coarser striation of the carapace valves, and by imperceptible pits posterior to minute lateral spines on the telson (see Chlupáč 1994).

Ceratiocaris inaequalis Barrande, 1872, which occurs in calcareous shales of middle and late Wenlock age, Motol Formation (Cyrtograptus rigidus to C. lundgreni zones), was referred by Chlupáč (1994) to his invalid subgenus Ceratiocaris (Bohemicaris). This species also somewhat resembles $C$. papilio in the general morphology of its abdominal segments but differs in having very prominent longitudinal ridges on the telson and especially by distinct longitudinal anastomose striation of A6 and A7 (see Barrande 1872, pl. 19, figs 14, 15). This type of striation is shared with $C$. bohemica Barrande, 1872, to which it was referred by Racheboeuf (1994), a view also supported by Collette \& Hagadorn (2010).

Ceratiocaris docens Barrande, 1872 occurs in Kopanina Formation (Ludlow), Ananaspis fecunda to Prionopeltis archiaci 'horizons', i.e. N. latilobus and M. fragmentalis zones) is another species considered to be of doubtful validity by Chlupáč (1994). Subsequent examination and phylogenetic analysis has confirmed this suspicion, and this species has been referred back to Ceratiocaris bohemica Barrande, 1872, which occurs in overlaying Požáry Formation of Přídolí age (see table 1 in Collette \& Hagadorn 2010 for synonymy). It was on the basis of $C$. bohemica that Chlupáč established the subgenus Ceratiocaris (Bohemicaris) to contain this and other ceratiocaridids with a short carapace lacking striations, an elongate and slender seventh abdominal segment, elongate telson and furcal rami (both with longitudinal ridges or striae) and abdominal and telson head sculpture (Chlupáč 1994). Collette \& Hagadorn (2010) subsequently located a partially complete specimen of $C$. bohemica in the collections of the Czech National Museum (L 21193) that confirms the presence of typical ceratiocaridid carapace valve ornamentation. All other characters on which this subgenus was based occur in other ceratiocaridid taxa, and this subgenus was considered by Collette \& Hagadorn (2010) as insufficiently differing from Ceratiocaris sensu stricto to be separated from this subgenus.

A thorough search of collections of the Prague National Museum, Charles University collections and the collections of the Czech Geological Survey have failed to locate other specimens previously attributable to $C$. papilio. Thus, the new material from the Všeradice section described herein represents the only occurrence of Ceratiocaris papilio currently known from Bohemia. The reconstruction of phyletic lines in Bohemian phyllocarids is difficult, and is complicated by variations in preservational style and a paucity of some species. Previously described specimens mentioned by O.P. Novák (MS) and I. Chlupáč (1994) to be

Figure 7. A, B, E-G-Ceratiocaris papilio Salter in Murchison, 1859. Lower Ludfordian, Silurian, Kopanina Formation, Všeradice, VŠ-2 pit. • A - articulated segment A7 and furca, CGS PB 507. • B - articulated segment A7 and furca, CGS PB 511. • C - articulated furca, showing smooth furcal rami and a telson with row of fine impressions, which match with attachment places of lateral spines, dorsal view, CGS PB 510. $\bullet$ D - Ceratiocaris sp. Lower Ludfordian, Silurian, Kopanina Formation, Všeradice, VŠ-2 pit. Isolated abdominal segment (A3-4?) with ornamentation consisting exclusively of fine striation, CGS PB 509. • E - isolated mandible, detail, CGS PB 512. • F - articulated segments A4-A7 with typical ornamentation, CGS PB 508. - G - clustered mandibles, CGS PB 513. - H- articulated segments A6+A7 with furca, CGS PB 506, showing typical ornamentation. Scale bars $\mathrm{A}-\mathrm{D}, \mathrm{F}-\mathrm{H}=1 \mathrm{~cm} ; \mathrm{E}=1 \mathrm{~mm}$. 
Petr Budil et al. • Phyllocariid crustacean Ceratiocaris papilio in the lower Ludfordian of Bohemia
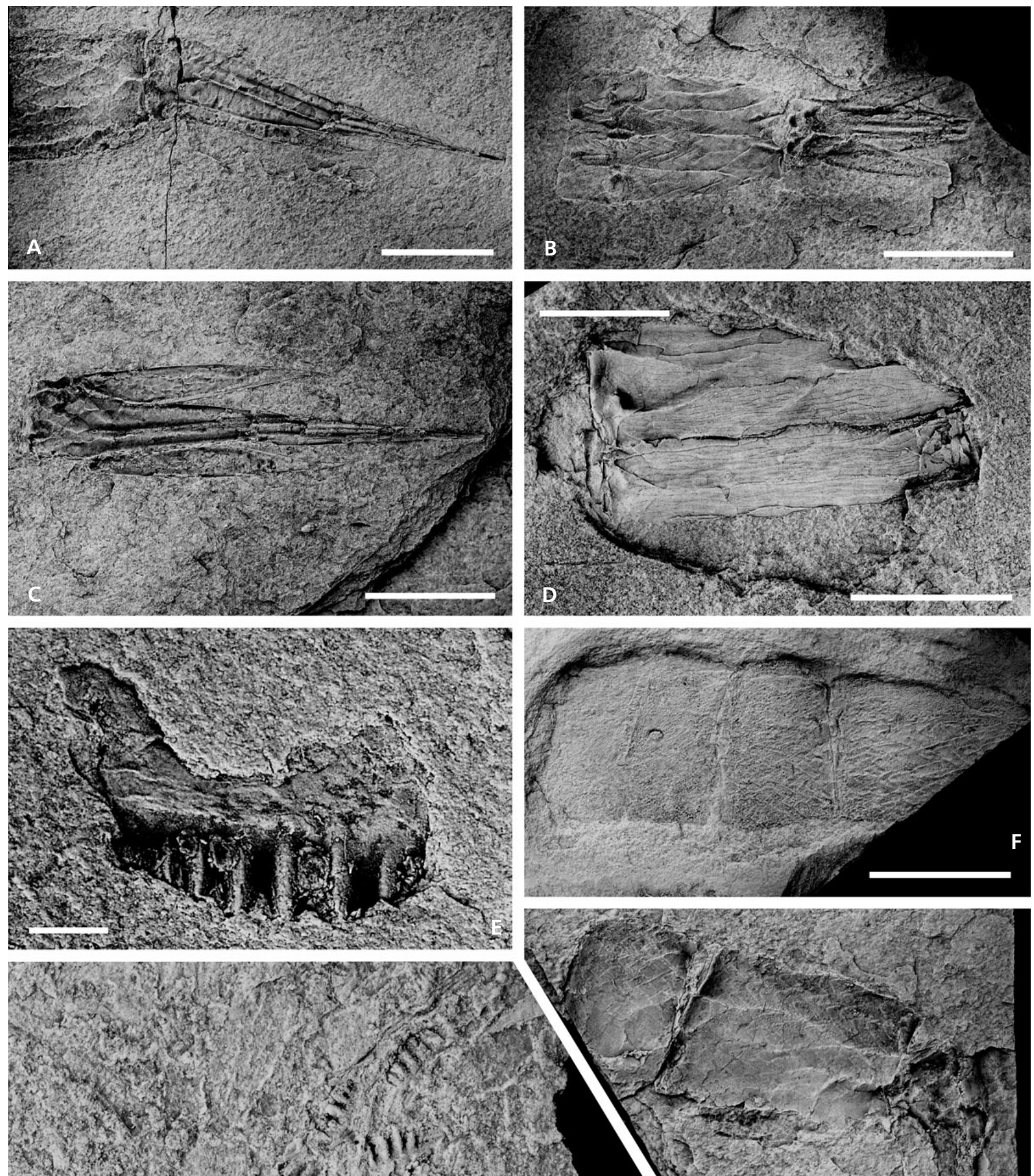

m.t.

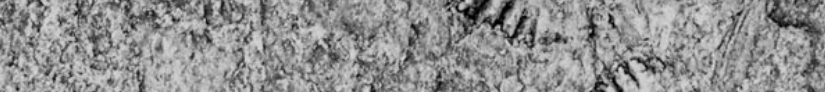

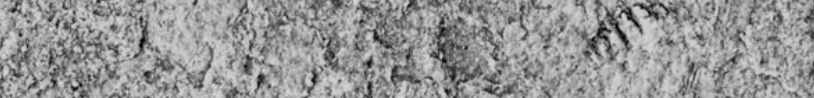

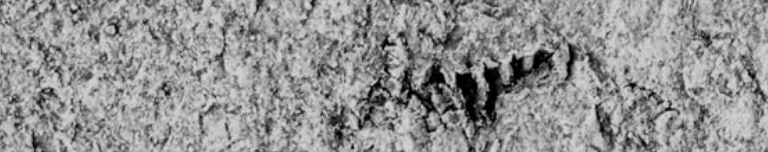

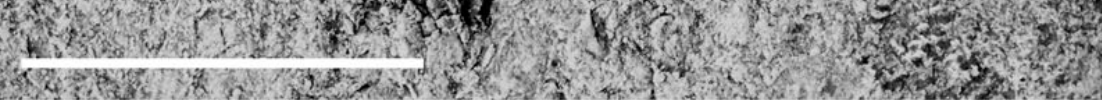

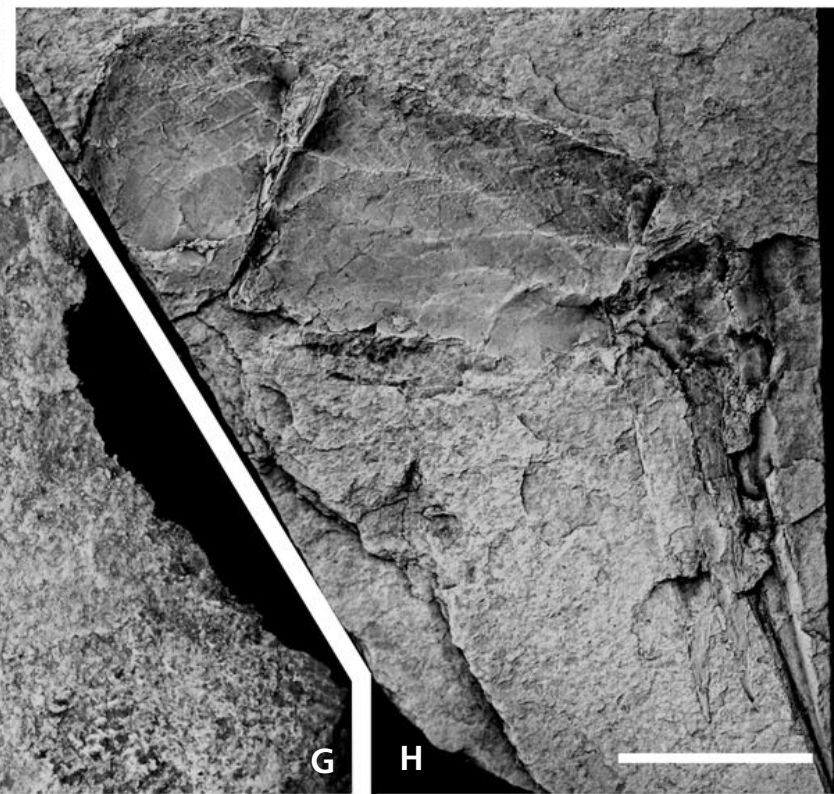



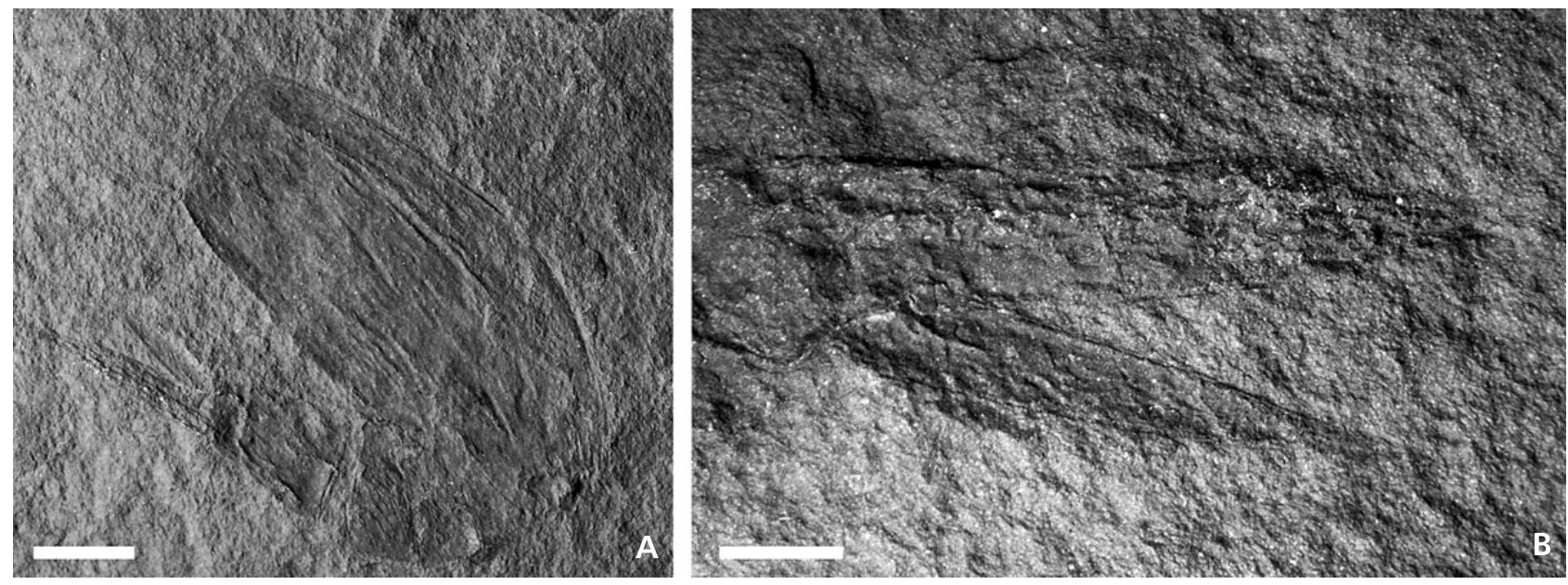

Figure 8. Scottish type specimen of C. papilio Salter in Murchison, 1859 (GSM 7479, neotype) photographed by P. Shepherd. • A - C. papilio neotype, entire specimen. $\cdot \mathrm{B}$ - detail of neotype illustrating the smooth furcal rami without longitudinal striae. $\mathrm{Scale}$ bars $\mathrm{A}=1 \mathrm{~cm} ; \mathrm{B}=2 \mathrm{~mm}$.

attributed to $C$. papilio have not been found in any collection. Among species occurring in Bohemia, Ceratiocaris papilio appears most closely related to the coeval C. scharyi. Warneticaris grata, which is common in Silurian-Devonian boundary strata also somewhat resembles Ceratiocaris papilio (Chlupáč 1984). It may be noted that Ceratiocaris papilio and allied forms inhabited rather more offshore environments, while Ceratiocaris bohemica and closely related taxa occur in shallower water environment.

\section{Conclusions and palaeogeographical consequences}

Silurian phyllocarids are considered to be deeper-water mud dwellers and nektonic predator-scavengers (Vannier et al. 1997, 2003; for an analogy with modern leptostracans see Mauchline 1984 and Lee \& Morton 2005). The palaeobiogeographic distribution of Silurian phyllocarids is still poorly known, but published data show rather high provinciality (Chlupáč 1994). This is remarkable because planktic and nektic marine animals generally show low provinciality in Silurian times; this is true in graptolites as well as cephalopods (e.g. Cocks \& Torsvik 2002, 2006). The occurrence of Ceratiocaris papilio in the Ludfordian of Bohemia is quite unexpected. Prior to the discovery of Bohemian material, this species was known only from the Llandovery and Wenlock of Laurentia (Collette \& Rudkin 2010). The presence of species related to $C$. papilio in the
Llandovery to Ludlow of Bohemia was suggested by Chlupáč (1984, 1994); however, at present, we cannot confirm these results with certainty.

The early Palaeozoic succession preserved in the Prague Synform of central Bohemia is a relict of a former rift-like structure called the Prague Basin (for summary see Kř́̌ž in Chlupáč et al. 1998). Based on palaeomagnetic data, the basin was situated in the southern hemisphere during the early Ludlow. Various authors have calculated the paleogeographic position of the basin to be approximately 28-25 S (Krs et al. 2001, Kříž et al. 2003), or alternatively, slightly to the north (Cocks \& Torsvik 2002, 2006), or to the south (Fatka \& Mergl 2009). The latitudinal position is generally accepted to be within this range. The longitudinal position of the basin, however, and relation to other terrains is still quite controversial. The Prague Basin was located on a separate micro-plate called Perunica by Havlíček et al. (1994) and Fatka \& Mergl (2009); alternatively, the Prague Basin may represent part of a Saxothuringian Assemblage Terrain (see Stampfli et al. 2002). Despite the general faunal similarity between Bohemia and peri-Gondwanan terrains, faunas from Bohemia contain many warm-water elements (see Manda 2008, Fatka \& Mergl 2009). The differences between Bohemia and other peri-Gondwanan terrains in faunal composition suggest higher water temperature than in other peri-Gondwanan basins.

Ceratiocaris papilio is a well-known and easily distinguished species. It is currently known from the late Llandovery and Wenlock of Scotland, Iowa, Wisconsin

Figure 9. A, B - Ceratiocaris scharyi Barrande, 1872. • A - articulated abdominal segments A1 to A7, negative counterpart, NM L 18823, holotype by monotypy, figured by Barrande (1872) on pl. 32, figs 24-29, loc. "Wohrada" = Praha-Ǩeporyje, Ludfordian, Silurian, Kopanina Formation, bioclastic limestone. • B - the same specimen, a detail of ornamentation. • C, D -Warneticaris grata (Chlupáč, 1984). $\bullet$ C detail of the ornamentation, holotype NM L 21191, figured by Chlupáč (1984) on pl. 1, figs 1-4, Požáry Formation, Velká Chuchle. • D - articulated abdominal segments A6+A7 plus furca, the same specimen. Scale bars $=1 \mathrm{~cm}$. 

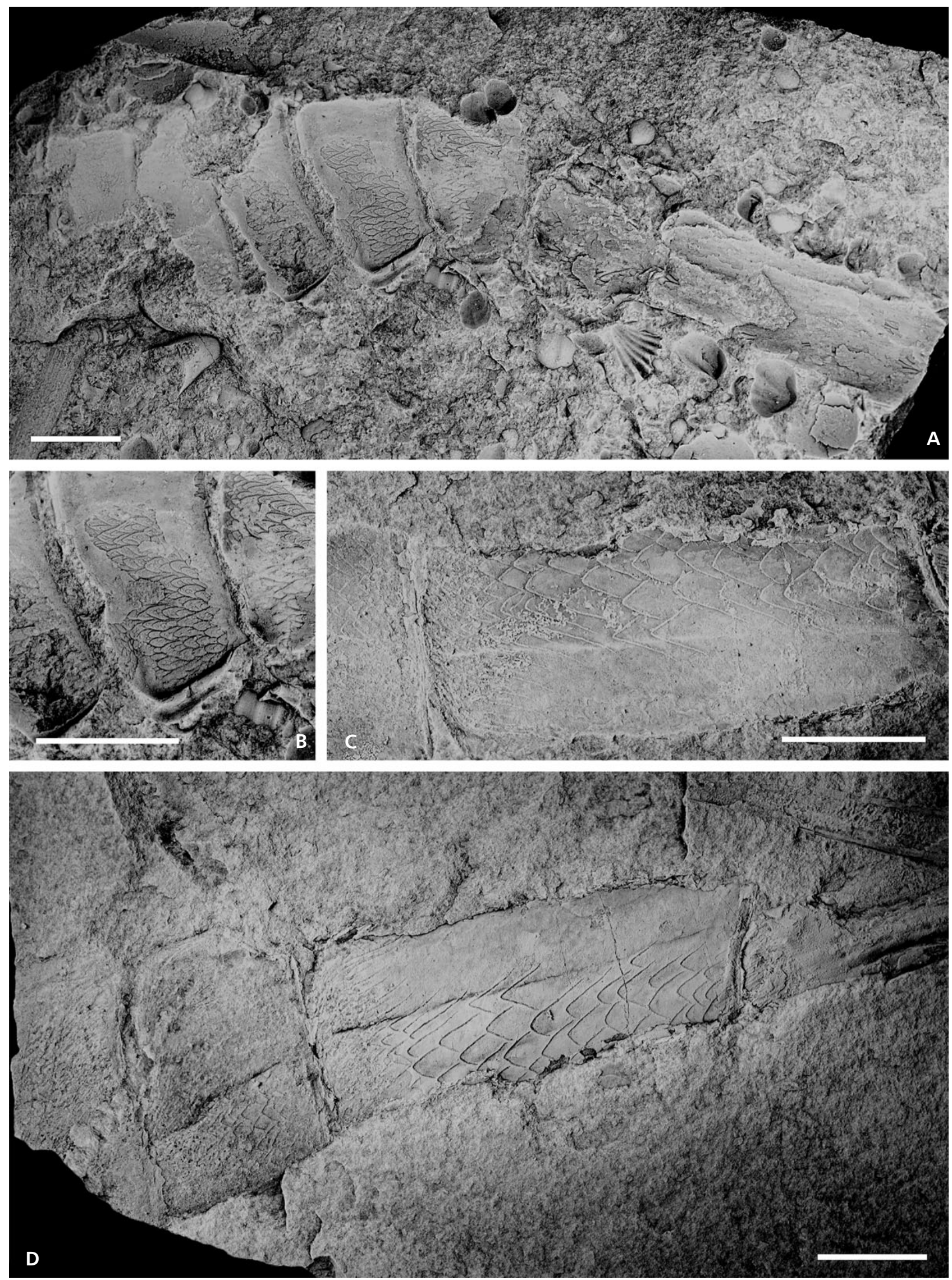


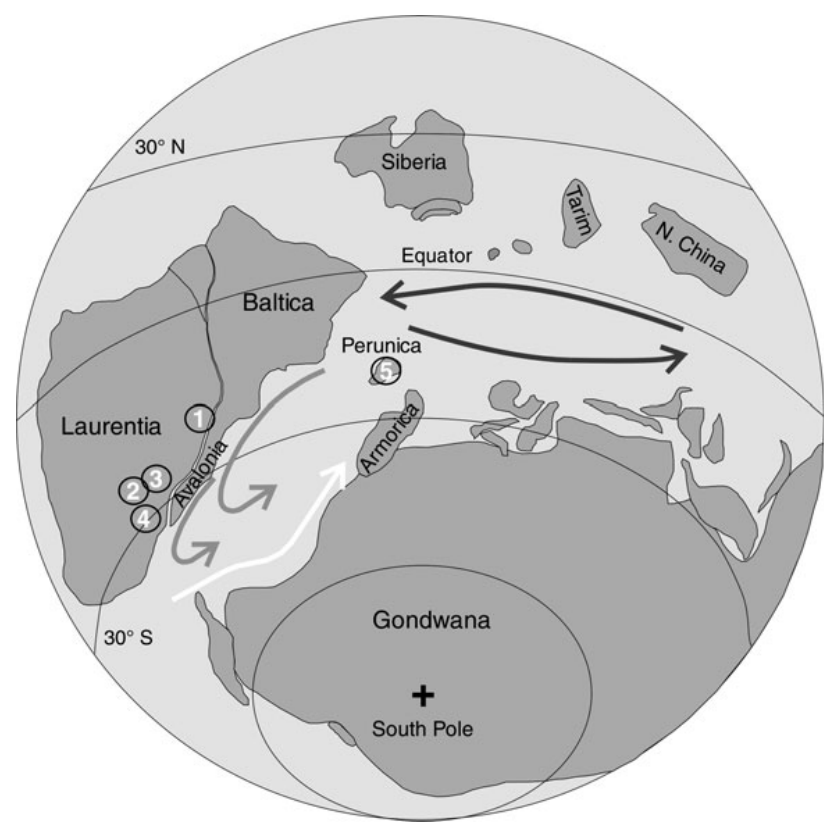

Figure 10. Hypothesized palaeogeographic map of the world in the early Ludlow (modified from Cocks \& Torsvik 2002, 2006, supplemented by data of Scotese \& McKerrow 1990, Wilde et al. 1991, Krs et al. 2001, Stampfli et al. 2002, Kř́̌ž et al. 2003 and Manda 2008). Hypothesized palaeogeographic position of the microcontinent Perunica slightly modified after Fatka \& Mergl (2010). Dark-colored circles with Nos 1-4 show supposed position of currently known occurrences of Ceratiocaris papilio after Collette \& Rudkin (2010): 1 - Lamarkshire, Scotland, UK (upper Llandovery to Wenlock); 2 - Waukesha, Wisconsin, USA (upper Llandovery); 3 - Wiarton, Ontario, Canada (Wenlock); 4 - Quincy, Iowa, USA (Wenlock). Number 5 represents supposed position of the new association from the Prague Basin (Ludlow, Ludfordian). Abbreviations: EQ - Equatorial Current; ST - South Tropical Current; SSP - South Subpolar Current. See discussion in the text.

and Ontario. Consequently, C. papilio represents an unequivocal Laurentian faunal element in the Prague Basin. No occurrence of Ceratiocaris papilio is currently known from northern Gondwana or peri-Gondwana. Ceratiocaris bohemica and Warneticaris cornwalensis, both common in Bohemia, are also known from Sardinia (Gnoli et al. 2009) and Armorica (Racheboeuf 1994). The Bohemian population of Ceratiocaris papilio is approximately $2 \mathrm{Ma}$ younger than those of Laurentia. The distribution pattern of C. papilio implies an open seaway between Laurentia and Bohemia.

However, there is still the problem of possible migration routes between Laurentia and peri-Gondwanan terrain. These should be severely limited by the paleogeographic position of Avalonia, which lay close to the eastern Laurentia margin in Silurian time (see Fig. 7). Such a location for a unified Avalonian terrane (e.g. not subdivided into the West and East Avalonia sub-terranes, since the Ordovician-Silurian transition fused with Baltica, sensu Cocks \& Fortey 2009) would be expected to cause at least a partial geographic barrier at that time, especially for a deeper-water fauna. Deeper water fau- nas might be expected to migrate across, or preferentially rather, along slopes. The same authors (Cocks \& Fortey 2009) suggest $425 \mathrm{Ma}$ (late Wenlock, mid-Homerian) as the probable timing of the closure of the Iapetus Ocean and the origin of Laurussia. A questionable occurrence of Ceratiocaris papilio, respective C. stygia? in Avalonia [e.g., at the Welsh Borderland (see Anderson 2007 and Jones \& Woodward 1888)], could not be confirmed here with certainty. Therefore, a possible scenario is presented in Fig. 10, in which the Ceratiocaris papilio population in the latest Wenlock appears to be using a migration route along the southern margin of Avalonia (after the closure of the Iapetus Ocean when deeper-water fauna should have migrated out of this area). In this scenario, it is possible that part of the C. papilio main population could have become entrained in the Southern Rheic Ocean Gyre Current and/or by the South Tropical Current sensu Wilde et al. (1991) and Manda (2008).

Even though material presented herein represents a fairly isolated and late occurrence of $C$. papilio, there are surprisingly few morphological differences when this population is compared with those known from Laurentia: e.g. smooth furcae in Czech specimens which also do not preserve the three hingeline nodes of the carapace, nor do they have the finer-scale trigonal micro-ornament 'overprinting' of the abdominal 'scales' preserved in Eramosa specimens. These differences might be explained by differing taphonomic conditions, or alternatively by small 'genetic drift'-like differences within populations or variability in a time-geographically constrained population. These minor morphological differences, however, in our opinion, do not exceed the limits of intra-specific variability already known in C. papilio. Ceratiocaris papilio appears to be a relatively long ranging taxon, with a range of perhaps 8.7 million years from the late Llandovery $(430 \pm 1.5 \mathrm{Ma})$ to the early Ludfordian $(421.3 \pm 2.6 \mathrm{Ma})$. Patchy or mosaic distribution patterns between populations suggests that Ceratiocaris papilio may have formed local populations with high abundance and ability to migrate over relatively long distances.

\section{Acknowledgements}

This work could not have been completed without the support of many colleagues, especially P. Štorch (Czech Academy of Science), who helped us with identification of the graptolite fauna and assisted in field excavations. Thanks to P. Shepherd from the British Geological Survey for locating and photographing C. papilio type material and to $\mathrm{V}$. Turek for his assistance in the collection of the Natural History Museum, Prague. The authors wish to thank both reviewers P. Racheboeuf and J. Bergström for their comments and critical remarks, which substantially improved the quality of manuscript. This work was supported by following grants: Grant Agency of the Czech Republic 205/09/0703; and Ministry of Culture of the Czech Republic VaV DE08P04OMG002. 


\section{References}

ANDERSON, L.I. 2007. Unmineralised arthropods, 133-156. In CLARKSON, E.N.K., HARPER, D.A.T., TAYLOR, C.M. \& ANDERSON, L.I. (eds) Silurian Fossils of the of Pentland Hills, Scottland. 218 pp. The Palaeontological Association, London.

BARRANDE, J. 1872. Systême silurien du centre de la Bohême, I. Privately published, Praha \& Paris.

BOUČEK, B. 1937. Graptolitová fauna českého spodního ludlowu. Rozpravy České akademie věd a umění II, 37(33), 1-60.

CHLUPÁČ, I. 1977. The phacopid trilobites of the Silurian and Devonian of Czechoslovakia. Rozpravy Ústředního ústavu geologického 43, 1-172.

CHLUPÁČ, I. 1984. A new phyllocarid crustacean from the topmost Silurian of Bohemia. Věstník Ústředního ústavu geologického 59(1), 41-43.

CHLUPÁČ, I. 1994. Assemblages of phyllocarid crustaceans in the Silurian and Devonian of Bohemia and their analogues. Geologica and Palaeontologica 28, 1-25.

Claus, C. 1888. Über den Organismus der Nebaliden und die systematische Stellung der Leptostraken. Arbeiten aus dem zoologische Institut der Universität Wien und der zoologischen Station in Triest 8, 1-148.

COCKS, L.R.M. \& FORTEY, R.A. 2009. Avalonia: a long-lived terrane in the Lower Palaeozoic?, 141-155. In BASSET, M.G. (ed.) Early Palaeozoic Peri-Gondwana Terranes: New Insights from Tectonics and Biogeography. Geological Society of London, Special Publications 325. London.

COCKS, L.R.M. \& TORSVIK, T.H. 2002. Earth geography from 500 to 400 million years ago: a faunal and palaeomagnetic review. Journal of the Geological Society of London 159(6), 631-644. DOI 10.1144/0016-764901-118

COCKS, L.R.M. \& TORSVIK, T.H. 2006. European geography in a global context from the Vendian to the end of the Palaeozoic, 83-95. In GEE, D.G. \& STEPHENSON, R.A. (eds) European Lithosphere Dynamics. Geological Society of London, Memoirs 32. London.

Collette, J.H. \& Hagadorn, J.W. 2010. Early evolution of phyllocarid arthropods: phylogeny and systematics of Cambrian-Devonian archaeostracans. Journal of Paleontology 84(5), 795-815. DOI 10.1666/09-092.1

COLLETTE, J.H. \& RUDKIN, D.M. 2010. Phyllocarid crustaceans from the Silurian Eramosa lagerstätte (Ontario, Canada): Taxonomy and functional morphology. Journal of Paleontology 84(1), 118-127. DOI 10.1666/08-174.1

Crasquin, S., RAcheboeuf, P.R. \& Bergström, J. 2009. Sensory structures of Archaeostraca (Phyllocaridida, Crustacea). Evolution \& Development 11(2), 225-232. DOI 10.1111/j.1525-142X.2009.00322.x

FATKA, O. \& MERGL, M. 2009. The "microcontinent" Perunica: status and story 15 years after conception, 65-101. In BASSETT, M.G. (ed.) Early Palaeozoic Peri-Gondwana Terranes: New Insights from Tectonics and Biogeography. Geological Society of London, Special Publications 325. London.

GNOli, M., Perrier, V. \& SERVENTI, P. 2009. The state of research on Sardinian Silurian Crustacea. Rendiconti della Societa Paleontologica Italiana 3, 143-155.

HAVlíčEK, V., VANĚK, J. \& FATKA, O. 1994. Perunica microcontinent in the Ordovician (its position within the Mediterra- nean Province, series division, benthic and pelagic associations). Sborník geologických věd, Geologie 46, 23-56.

HORNÝ, R. 1955. The Budňany Beds in the western part of the Barrandian. Sborník Ústředního ústavu geologického, Oddíl geologický 21, 315-447.

HORNÝ, R. 1960. Stratigraphy and tectonics of the western closures of the Silurian and Devonian in the area between Liten and Suchomasty (English summary). Sborník Ústředního ústavu geologického, Oddíl geologický 26(1), 495-524.

JOHNSON, M.E., RONG, JiA-Yu \& KERSHAW, S. 1998. Calibrating Silurian eustasy against the erosion and burial of coastal paleotopography, 3-13. In LANDING, E. \& JOHNSON, M.E. (eds) Silurian cycles: linkages of dynamic stratigraphy with atmospheric, oceanic and tectonic changes. James Hall Centennial Volume, New York State Museum Bulletin 491.

JONES, R.T. \& WoODWARD, H. 1888. A Monograph of the British Palaeozoic Phyllopoda (Phyllocarida, Packard). Part I. Ceratiocaridae. 72 pp. Palaeontological Society, London.

KozlowsKA-DAwIDZIUK, A., LENZ, A.C. \& ŠTORCH, P. 2001. Upper Wenlock and Lower Ludlow (Silurian) graptolites; Všeradice section, Barrandian area, Czech Republic. Journal of Paleontology 75, 147-164.

DOI 10.1666/0022-3360(2001)075<0147:UWALLS>2.0.CO;2

KŘíž, J. 1991. The Silurian of the Prague Basin (Bohemia) - tectonic, eustatic and volcanic controls on facies and faunal development, 179-203. In BASSETT, M.G., LANE, P.D. \& EDWARDS, D. (eds) The Murchison Symposium: proceedings of an international conference on the Silurian System. Special Papers in Palaeontology 44, 1-397.

KŘíž, J. 1992. Silurian Field Excursions: Prague Basin (Barrandian), Bohemia. National Museum Wales, Geological Series $13,1-111$.

KŘíž, J. 1998. Silurian. In CHLUPÁČ, I., HAVLÍČEK, V., KŘí̌̌, J., KukAl, Z. \& ŠTORCH, P. Palaeozoic of the Barrandian (Cambrian to Devonian). 183 pp. Czech Geological Survey, Praha.

KŘíž, J., DUFKA, P., JAEGER, H. \& SCHÖNLAUB, H.P. 1993. The Wenlock/Ludlow boundary in the Prague Basin (Bohemia). Jahrbuch der Geologischen Bundesanstalt A 136(4), 809-839.

KŘíž, J., Degardin, J.M., Ferretti, A., Hansch, W., GutTIÉREZ-MARCO, J.C., PARIS, F., PICARrA, D., AlmEIDA, J.M., Robardet, M., SchÖNlaUb, H.P. \& Serpagli, E. 2003. Silurian stratigraphy and paleogeography of Gondwanan and Perunican Europe. New York State Museum Bulletin 493, 105-178.

KRS, M., PRuner, P. \& MAN, O. 2001. Tectonic and paleogeographic interpretation of the paleomagnetism of Variscan and pre-Variscan formations of the Bohemian Massif, with special reference to the Barrandian terrane. Tectonophysics 332, 93-114. DOI 10.1016/S0040-1951(00)00251-1

LATREILlE, P.A. 1806. Genera Crustaceorum et Insectorum secundum ordinem naturalem in familias disposita, iconibus exemplurisque plurimis explicata. 302 pp. Paris \& Argentorati.

LeE, C.N. \& Morton, B. 2005. Demography of Nebalia sp. (Crustacea: Leptostraca) determined by carrion bait trapping in Lobster Bay, Cape d'Aguilar Marine Reserve, Hong Kong. Marine Biology 148, 149-157.

DOI 10.1007/s00227-005-0051-0 
MANDA, Š. 2008. Palaeoecology and palaeogeographic relations of the Silurian phragmoceratids (Nautiloidea, Cephalopoda) of the Prague Basin (Bohemia). Bulletin of Geosciences 83(1), 39-62. DOI 10.3140/bull.geosci.2008.01.039

MANDA, Š. \& KŘíž, J. 2006. Environmental and biotic changes in subtropical isolated carbonate platforms during the Late Silurian Kozlowskii Event, Prague Basin. GFF 128, 161-168.

MAUCHLINE, J. 1984. Euphausiid, Stomatopod and Leptostracan crustaceans, 1-93. In KERMACK, D.M. \& BARNES, E.S.K. Synopses of British fauna (New Series) 30. Linnean Society of London \& The estuarine and Brackisch-water Sciences Association.

MELChIN, M.J., KOREN', T.N. \& ŠTORCH, P. 1998. Global diversity and survivorship patterns of Silurian graptoloids, 165-182. In LANDING, E. \& JOHNSON, M.E. (eds) Silurian Cycles: Linkages of Dynamic Stratigraphy with Atmospheric, Oceanic and Tectonic Changes. New York State Museum Bulletin 491.

M'COY, F. 1849. On the classification of some British fossil Crustacea, with notices of new forms in the University of Cambridge. The Annals and Magazine of Natural History 2(4), 412-414.

NovÁK, O. 1887. Phyllopoda. Systême Silurien du Centre de la Bohême, Supplément au Vol. I., part II. Manuscript deposited in the National Museum in Prague.

PACKARD, A.S. 1879. A monograph of the Phyllopod Crustacea of North America, with remarks on the order Phyllocarida. $12^{\text {th }}$ Report of the U.S. Geological Survey Territories 12, 295-592.

RACHEBOEUF, P.R. 1994. Silurian and Devonian phyllocarid crustaceans from the Massif Armoricain, NW France. Revue de Paléobiologie 13, 281-305.

ROLFE, W.D.I. 1961. A preliminary study of the Silurian cera- tiocaridids (Crustacea: Phyllocarida) of Lesmahagow, Scotland. Breviora, Museum of Comparative Zoology 149, 1-9.

ROLFE, W.D.I. 1962. Grosser morphology of the Scottish Silurian phyllocarid crustacean Ceratiocaris papilio Salter in Murchison. Journal of Paleontology 36, 912-932.

ROLFE, W.D.I. \& BURNABY, P.T. 1961. A preliminary study of the Silurian ceratiocaridids (Crustacea; Phyllocarida) of Lesmahagow, Scotland. Breviora 149, 1-9.

SALTER, J.W. 1859. Organic remains from the Durness Limestone. In MURCHISON, R.I. On the succession of the older rocks in the northernmost counties of Scotland; with some observations on the Orkney and Shetland Islands. Quarterly Journal Geological Society of London 15, 262-418.

SALTER, J.W. 1863. Note on the Skiddaw Slate fossils. Quarterly Journal of the Geological Society of London 19, 135-140.

StAMPFLI, G.M, RAUMER, J.F \& BOREL, G.D. 2002. Paleozoic evolution of pre-Variscan terranes: From Gondwana to the Variscan collision. Geological Society of America Special Paper 364, 263-280.

VANNIER, J., BOISSY, P. \& RACHEBOEUF, P.R. 1997. Locomotion in Nebalia bipes: a possible model for Palaeozoic phyllocarid crustaceans. Lethaia 30, 89-104. DOI 10.1111/j.1502-3931.1997.tb00449.x

VANNIER, J., RACHEBOEUF, P.R., BRUSSA, E., Williams, M., Rushton, A.W.A., SERVAis, T. \& Siveter, D.J. 2003. Cosmopolitan arthropod zooplankton in Ordovician seas. Palaeogeography, Palaeoclimatology, Palaeoecology 195, 173-191. DOI 10.1016/S0031-0182(03)00307-9

WILDE, P., BERRY, W.B.N. \& QUINBY-HUNT, M.S. 1991. Silurian oceanic and atmospheric circulation and chemistry. Special Papers in Palaeontology 44, 123-143.

\section{Appendix}

Abundance of Ceratiocaris papilio at Všeradice VŠ 2 section. A means abdominal segment.

\begin{tabular}{|c|c|c|c|c|c|c|c|c|c|c|}
\hline No. of bed & 42 & 46 & 48 & 52 & 56 & 58 & 60 & 62 & Rock debris & Summa \\
\hline "Incomplete specimen" & & & & & & & 1 & & & 1 \\
\hline A4567 & & & & & & & & 1 & 1 & 2 \\
\hline A567 & & & & & 2 & 2 & 1 & & & 5 \\
\hline A67 & & & & & 5 & 1 & 1 & & 1 & 8 \\
\hline A7 & & 1 & 1 & & 4 & 4 & & 2 & & 12 \\
\hline Furca & & & & 6 & 19 & 20 & 5 & 14 & 20 & 84 \\
\hline Fragment of carapace & & & & & & 1 & & & & 1 \\
\hline Telson & 3 & & & & 10 & 11 & 2 & 6 & 5 & 37 \\
\hline Mandibles & & & & 1 & 16 & 31 & 4 & 10 & 4 & 66 \\
\hline Other remains & & & & & & 1 & 2 & 2 & 2 & 7 \\
\hline Summa & 3 & 1 & 1 & 7 & 56 & 71 & 16 & 35 & 33 & 223 \\
\hline
\end{tabular}

